\title{
ANALISIS PERILAKU KONSUMEN PEREMPUAN TERHADAP KESEHATAN REPRODUKSI DAN PERILAKU PENGGUNAAN PEMBALUT
}

\author{
Julina \\ Fakultas Ekonomi dan Ilmu Sosial UIN Suska Riau \\ E-mail: julina22@ymail.com
}

\begin{abstract}
This research try to discover women consumer behavior towards their reproductive health and the use of pads. It was found that most respondent used magazines, newspapers, or newspapers as sources of information to acquire knowledge about reproductive health. Respondents spent special time to increase knowledge about reproductive health of women and prioritize read articles about women's reproductive health. Pads is one of product that is familiar with the women reproductive health, but women in this study had no certainty about its safety for use and whether the pads can cause cancer. Additionally, more than half of respondents would consider using the traditional way with a washable cloth pads if the current pads is proven can cause cervical cancer. Price of the pads is a factor that affects their purchase behavior and although they have a favorite brand, they are not particularly loyal to the brand if it is not available when needed.
\end{abstract}


Kata Kunci: kesehatan reproduksi, pembalut, perilaku konsumen perempuan.

\section{PENDAHULUAN}

Perempuan memiliki peran penting dalam berbagai aspek kehidupan. Dewasa ini, perannya semakin menonjol seiring dengan peningkatan kesempatan dan potensi yang dimiliki. Untuk menunjang keberhasilan menjalankan perannya, kesehatan perempuan perlu mendapatkan perhatian. Salah satu masalah kesehatan yang dihadapai perempuan adalah masalah kesehatan reproduksinya. Upaya menjaga kesehatan reproduksi seyogyanya dimulai sejak dini dan secara terus menerus seiring dengan meningkatnya risiko berbagai penyakit yang menyerang reproduksi perempuan. Penelitian yang dilakukan di 15 negara menyatakan bahwa pekerja perempuan merupakan kategori yang penting untuk diperhatikan dari sudut pandang kesehatan kerja. ${ }^{1}$

Selain berdampak terhadap kesuksesan peran yang dijalankannya, kesehatan reproduksi juga menjadi hal yang sangat penting untuk kelanjutan generasi berikutnya. Sesuai dengan kodratnya, perempuan merupakan pencetak generasi selanjutnya. Ada sebagian perempuan tidak dapat menghasilkan keturunan karena memiliki masalah pada alat reproduksinya. Rahim, organ reproduksi perempuan yang seharusnya menjadi tempat untuk tumbuh dan berkembang janin tidak dapat menjalankan fungsinya dengan baik. Terdapat banyak penyakit yang dapat menyerang reproduksi perempuan. Salah satu penyakit yang menyerang reproduksi perempuan adalah kanker leher rahim (serviks). Berdasarkan data dari badan kesehatan dunia (WHO), kanker serviks merupakan kanker nomor dua terbanyak pada perempuan berusia 15-45 tahun setelah kanker payudara. Tidak kurang dari 500.000 kasus baru dengan kematian 280.000 penderita terjadi setiap tahun diseluruh dunia. Bisa dikatakan, setiap dua menit seorang perempuan meninggal akibat kanker serviks. Di Wilayah Asia Pasifik dan Timur Tengah ada 1,3 milyar perempuan berusia 13 tahun ke atas yang beresiko terkena kanker serviks. WHO memperkirakan ada lebih dari 265.000 kasus kanker serviks dengan kematian 140.000 penderita setiap tahun di wilayah ini. Menurut data Globocan 2002, terdapat lebih dari 40.000 kasus baru kanker serviks dengan sekitar 22.000 kematian karenanya pada perempuan di Asia Tenggara. ${ }^{22}$

Kanker serviks dapat dicegah melalui perilaku yang sehat terkait dengan reproduksi dan melalui pemeriksaan dini. Dewasa ini banyak rumah sakit yang telah menyediakan jasa pendeteksian kanker yang 
disebut Pap Smear. Para perempuan kini sudah lebih mudah mengakses jasa kesehatan reproduksi jika mereka mau dan mampu.

Terkait dengan kesehatan reproduksi yang secara periodik dihadapi perempuan adalah higienitas pada saat menstruasi. Bagaimana perilaku perempuan, khususnya dalam penggunaan pembalut terkait dengan mengatasi masalah pada masa menstruasi juga dapat mempengaruhi kesehatan reproduksinya. Makalah ini mencoba menggali tentang bagaimana perilaku konsumen perempuan terkait dengan kesehatan reproduksinya dan perilaku penggunaan pembalut. Hal ini penting untuk dilakukan agar para perempuan mendapatkan tambahan pengetahuan mengenai kesehatan reproduksi sehingga dapat menunjang aktivitas, tugas, fungsi, dan perannya sehari-hari.

\section{TINJAUAN TEORITIS}

\section{Kesehatan Reproduksi}

Perawatan kesehatan reproduksi didefinisikan sebagai konstelasi seluruh metode, teknik dan layanan yang berkontribusi terhadap kesehatan reproduksi dan kesejahteraan dengan mencegah dan memecahkan masalah kesehatan reproduksi. ${ }^{3}$ Definisi lain menyatakan, pengertian kesehatan reproduksi adalah suatu keadaan kesehatan yang sempurna baik secara fisik, mental, dan sosial dan bukan semata-mata terbebas dari penyakit atau kecacatan dalam segala aspek yang berhubungan dengan sistem reproduksi, fungsi serta prosesnya. Menurut WHO, kesehatan reproduksi adalah suatu keadaan fisik, mental dan sosial yang utuh, bukan hanya bebas dari penyakit atau kecacatan dalam segala aspek yang berhubungan dengan sistem reproduksi, fungsi serta prosesnya. Selain itu, definisi kesehatan reproduksi menurut hasil ICPD 1994 di Kairo adalah keadaan sempurna fisik, mental dan kesejahteraan social, tidak semata-mata ketiadaan penyakit atau kelemahan, dalam segala hal yang berkaitan dengan sistem reproduksi dan fungsi dan proses. Pengertian kesehatan reproduksi ini mencakup tentang hal-hal sebagai berikut: (1) Hak seseorang untuk dapat memperoleh kehidupan seksual yang aman dan memuaskan serta mempunyai kapasitas untuk bereproduksi; (2) Kebebasan untuk memutuskan bilamana atau seberapa banyak melakukannya; (3) Hak dari laki-laki dan perempuan untuk memperoleh informasi serta memperoleh aksebilitas yang aman, efektif, terjangkau baik secara ekonomi maupun kultural; 4) Hak untuk mendapatkan tingkat pelayanan kesehatan yang memadai sehingga perempuan mempunyai kesempatan untuk menjalani proses kehamilan secara aman. ${ }^{4}$ 
Masalah kesehatan reproduksi mendapat perhatian dari seluruh negara di dunia, bukan hanya masalah dalam skala nasional, akan tetapi juga dalam skala internasional. Pada tahun 2006 PBB menganggarkan dana sekitar 28 juta dollar Amerika ke Vietnam dalam kerjasama selama lima tahun (2006-2010) untuk mengatasi masalah populasi dan kesehatan reproduksi. Rencana kesehatan reproduksi bertujuan untuk meningkatkan ketersediaan pusat pelayanan kesehatan reproduksi yang berkualitas dan memacu penggunaan pusat-pusat kesehatan ini secara efektif untuk masyarakat. Intervensi utama akan ditargetkan pada peningkatan kesehatan ibu dan bayi dan kesehatan seksual dan reproduksi, termasuk pencegahan infeksi menular seksual, HIV/AIDS dan kehamilan yang tidak diinginkan dalam kelompok-kelompok rentan termasuk anak muda, orang tua tunggal, etnis minoritas dan pekerja migran miskin. ${ }^{5}$

Dalam pidatonya memperingati hari perempuan internasional (Internationa Women's Day atau IWD) pada tahun 2007, Dr. Margaret Chan, direktur jenderal WHO menyatakan kesehatan perempuan diberi ruang terlalu kecil dalam rencana pengembangan dan terlalu sedikit perhatian dalam banyak agenda kesehatan. Kesehatan perempuan terancam karena kondisi yang buruk ditempat perempuan bekerja, risiko yang dihadapi dalam peran reproduksi, dan diskriminasi dan kemiskinan yang dihadapi oleh perempuan.

Kemiskinan merupakan hambatan terbesar untuk pengembangan dan perubahan. Kemiskinan bertanggung jawab atas sebagian besar kematian dari penyebab yang seharusnya bisa dicegah. Di setiap negara, kemiskinan muncul sebagai penyebab tingginya tingkat kematian ibu dan anak dan tingkat kematian dan penyakit dari penyakit menular. Kesehatan perempuan jelas berisiko ketika mereka memiliki sedikit uang, tidak ada obat dan tidak ada akses untuk pencegahan atau jasa pengobatan. Hal ini sering diperparah oleh norma-norma sosial yang tidak memberikan perempuan kesempatan yang sama. WHO bekerja untuk mengatasi kerentanan dan kebutuhan kesehatan perempuan, memenuhi kebutuhan kesehatan reproduksi dan seksual perempuan, mencegah kekerasan terhadap perempuan dan untuk mengurangi infeksi, cedera, penyakit kronis, masalah kesehatan mental, dan kondisi kronis lainnya yang mempengaruhi perempuan. ${ }^{6}$

Penelitian yang dilakukan oleh Geronimus (1987), menemukan bahwa masalah-masalah kesehatan reproduksi yang dihadapi terutama disebabkan oleh status ekonomi dibandingkan umur. Status ekonomi perempuan didefinisikan dan diukur dalam berbagai cara. Ini meliputi tingkat pendapatan, pekerjaan, dan besar pencari nafkah dalam rumah 
tangga. Kebanyakan penelitian dilakukan telah menemukan bahwa pemanfaatan fasilitas kesehatan oleh ibu meningkat seiring dengan peningkatan status ekonomi mereka. ${ }^{7}$ Selain terjangkaunya biaya perawatan kesehatan, terapat beberapa faktor yang mempengaruhi perempuan memeriksakan kesehatan reproduksi. Hasil temuan empiris di India menyatakan bahwa ketersediaan dokter, waktu menunggu, kebersihan, privasi, dan terjangkaunya biaya perawatan kesehatan reproduksi meningkatkan kemungkinan fasilitas kesehatan ini akan digunakan untuk berbagai tujuan kesehatan reproduksi. ${ }^{8}$

Tujuan kesehatan reproduksi adalah keamanan reproduksi yang dapat dicapai ketika individu dan rumah tangga dapat mengidentifikasi, mencegah, dan mengelola risiko kesehatan reproduksi. Keamanan reproduksi ditingkatkan melalui lingkungan yang mendukung pada level masyarakat, institusi, dan kebijakan. Ada enam langkah penting untuk mencapai tujuan ini, analisis risiko reproduksi, mendorong perilaku reproduksi yang sehat, penguatan masyarakat, pembangunan kapasitas institusional, penggunaan teknologi kesehatan yang optimal, dan advokasi kebijakan publik. ${ }^{9}$

Berbagai faktor dapat mempengaruhi kesehatan reproduksi perempuan. Konsekuensi dari peningkatan industrialisasi dan pencemaran lingkungan adalah peningkatan penggunaan bahan kimia sintetis dan paparan berulang untuk senyawa berbahaya di tempat kerja dan di rumah berakibat buruk pada kesehatan reproduksi. Senyawa biohazardous, beberapa di antaranya mengganggu endokrin, semakin terlibat dalam meningkatkan infertilitas, ketidakteraturan menstruasi, aborsi spontan, cacat lahir, endometriosis, dan kanker payudara. Dalam beberapa kasus, perempuan berada pada risiko yang lebih besar dari pria, terutama dengan meningkatnya estrogen lingkungan. Hanya sebagian kecil dari bahan kimia ini telah diperiksa tingkat toksinitasnya dan efek sinergis dari berbagai paparan dari zat berbahaya. Oleh sebab itu, muncul suatu kebutuhan untuk kesadaran yang lebih besar dan kewaspadaan terhadap efek pencemaran lingkungan terhadap kesehatan reproduksi.

Aktivitas fisik jangka panjang dengan intensitas yang tinggi telah lama dikaitkan dengan perubahan sekresi hormon reproduksi. Perubahan endokrinologi perempuan dapat merubah fungsi reproduksi baik secara langsung maupun tidak langsung, dan pada kasus yang paling parah menyebabkan kemandulan. Evaluasi literatur menunjukkan bahwa aktivitas berat dapat membebani kesuburan perempuan. Infertilitas pada perempuan yang aktif secara fisik dapat disebabkan oleh adaptasi endokrinologis, perubahan komposisi tubuh dan kekurangan gizi. Untuk 
mengurangi risiko disfungsi reproduksi, perempuan harus memastikan bahwa jenis dan intensitas aktivitas fisik yang seimbang dengan diet memadai dalam energi. Hal ini harus didukung dengan berat badan yang sehat dan konten lemak tubuh yang memadai, dalam rentang yang direkomendasikan. Meskipun para perempuan mungkin pulih kembali, dan fungsi ovarium dapat dinormalkan, keseimbangan energi negatif dalam jangka panjang kemungkinan akan membatasi keberhasilan reproduksi. ${ }^{11}$

Secara lebih luas, liberalisasi perdagangan juga berpengaruh terhadap kesehatan reproduksi perempuan melalui adanya pernjanjian antar pemerintah untuk menurunkan atau menghilangkan hambatan perdagangan sehingga suplay barang dan jasa untuk mendukung kesehatan reproduksi perempuan semakin banyak. Kaitan lain antara liberalisasi perdagangan dan kesehatan reproduksi perempuan adalah terbukanya kesempatan kerja bagi perempuan menjadi pekerja di pabrikpabrik untuk memenuhi kebutuhan ekspor. Namun apakah terbukanya kesempatan kerja bagi para perempuan ini berpengaruh terhadap kesejahteraan dan kesehatan reproduksi, sangat tergantung pada konteksnya. Di Bangladesh, banyaknya pabrik baru berdampak positif pada penundaan pernikahan, meningkatkan otonomi dan ekonomi rumah tangga, dan meningkatkan penghasilan secara keseluruhan. Di Meksiko para perempuan terbebas dari permasalahan domestik, akses terhadap jasa pelayanan kesehatan, kemampuan meningkatkan kondisi kehidupan mereka, menyekolahkan anak-anaknya, dan terhindar dari perlakuan kasar dari pasangannya. Di China, pengembangan perusahaan swasta membuat penduduk pedesaan perempuan, khususnya yang berusia muda, untuk berpindah ke jenis pekerjaan yang bukan di bidang pertanian. Pengalaman mereka di kota meningkatkan kesehatan mereka dibandingkan dengan teman-temannya didesa karena adanya peningkatkan pendapatan, perubahan gaya hidup, dan akses terhadap pelayanan kesehatan. Akan tetapi terjadinya perubahan untuk bekerja di perusahaan swasta di kota juga memiliki dampak negatif bagi para perempuan pekerja, yang berasal dari keterbatasan jasa pelayanan kesehatan, tekanan yang diberlakukan oleh kebijakan keluarga berencana, kondisi kehidupan dan pekerjaan yang terkadang tidak sehat, dan peningkatkan kemungkinan para perempuan ini akan melakukan seks yang tidak aman. ${ }^{12}$

Dari sudut pandang gender, gender memiliki sesuatu kekuatan yang besar dalam masalah kesehatan reproduksi. Kompleksitas pembuatan keputusan rumah tangga dalam kesehatan reproduksi 
sebagian besar dari perbedaan peran pria dan perempuan. Diskriminasi gender mempunyai konsekuensi negatif baik untuk pria maupun perempuan, namun perempuan lebih banyak mengalami kerugian. Gender mempengaruhi kesehatan reproduksi setidaknya melalui: (1) Akses terhadap asset, bahwa perempuan memiliki lebih sedikit akses terhadap pendapatan dan barang-barang modal yang dapat digunakan untuk mendapatkan perawatan kesehatan; (2) Pembuatan keputusan tentang kesehatan reproduksi; (3) Nilai yang diberikan terhadap kesehatan dan kehidupan perempuan; (4) Harapan terhadap perilaku reproduksi. Perempuan sering diharapkan untuk memiliki banyak anak, terutama anak lelaki; (5) Kekerasan dan ancaman kekerasan. Perempuan sering menjadi subyek dari berbagai bentuk kekerasan yang memiliki dampak langsung dan tidak langsung terhadap kesehatan reproduksi. ${ }^{13}$

Sebuah penelitian yang dilakukan di Nigeria menemukan bahwa 43 persen dari respondennya pernah mengalami pelecehan seksual, sementara 28 persennya pernah diperkosa. Selain itu, ditemukan pula bahwa 70 persen dari sampel penelitian tidak mengetahui kemana mengakses pelayanan kesehatan reproduksi. ${ }^{14}$

Salah satu penyakit yang menyerang kesehatan reproduksi adalah kanker rahim. Kanker rahim merupakan penyakit yang berbahaya jika tidak segera diatasi dan dilakukan tindakan pencegahan sejak dini. Beberapa penelitian menyebutkan bahwa kanker ini disebabkan oleh virus Human Papilloma Virus (HPV). Virus ini muncul, antara lain disebabkan oleh perilaku sering berganti-ganti pasangan seks dan perilaku yang tidak higienis pada saat menstruasi. Di Indonesia, ditemukan bahwa penyebab utama kanker mulut rahim adalah pembalut berkualitas buruk. ${ }^{15}$ Kemungkinan seorang perempuan dewasa terjangkit infeksi vagina adalah $83 \%$. Selanjutnya $62 \%$ dari statistik tersebut disebabkan oleh pemakaian pembalut biasa. Menurut penelitian terdapat sebanyak 107 bakteri per milimeter persegi ditemukan di atas pembalut perempuan biasa, kondisi inilah yang membuat pembalut biasa menjadi sumber sarang pertumbuhan bakteri merugikan, meski pembalut biasa hanya dipakai selama 2 jam saja. ${ }^{16}$

\section{Pembalut Wanita}

Memasuki usia remaja/akil baligh, setiap perempuan akan mengalami suatu masa yang disebut menstruasi. Proses ini merupakan hal alamiah karena terjadinya pelepasan dinding rahim (endometrium) yang disertai dengan pendarahan. Rataan menstruasi dimulai saat perempuan berusia sekitar 10/11 tahun dan biasanya berhenti sekitar usia 
45-55 tahun. Masa sepanjang itu seorang perempuan akan membutuhkan pembalut agar tetap dapat beraktivitas dalam hari-hari haidnya.

Sejak zaman dahulu, ternyata perempuan sudah berusaha melakukan segala cara agar merasa nyaman selama menstruasi. Pada zaman Mesir kuno para perempuan menggunakan kapas yang dilapisi dengan kertas papyrus. Di Abad ke-10, bangsa Suda mencatat dimana Ratu Hypatia yang hidup pada awal abad ke-4 menggunakan kain untuk mengatasi masalah haid. Tahun 1986-an, pertama kali pembalut dibuat secara modern yang bahannya berasal dari woodpulp (bubur kayu) dan dapat langsung dibuang. Tahun 1990-an, diciptakan berbagai jenis yaitu ada yang lebih tipis (Pantyliner), penyerapannya berada ditengah thin/tipis dan maxi (Regular), penyerapannya sangat tinggi, biasanya digunakan saat haid sedang banyak (Maxi), digunakan saat malam dan lebih panjang (Night), digunakan bagi ibu setelah melahirkan/masa nifas (Maternity). ${ }^{17}$

Pembalut wanita, termasuk klasifikasi produk konsumer cepat saji dan produk sekali pakai. Karena itulah para produsen pembalut biasa kerap mendaur ulang bahan sampah kertas bekas dan menjadikan sampah kertas bekas ini menjadi bahan dasar untuk menghemat biaya produksi. Dalam proses daur ulang ini banyak bahan kimia digunakan untuk menghilangkan bau, memutihkan/bleaching, dan proses sterilisasi kuman-sehingga dari proses tersebut justru timbul zat Dioxin, yang sangat berbahaya terhadap reproduksi perempuan. Sementara pihak industri menyatakan bahwa produk-produk mereka aman digunakan, studi-studi yang dilakukan oleh institusi riset yang independen menyatakan bahwa produk-produk mereka benar-benar mengandung dioksin pada tingkatan yang rendah, yang sudah terbukti membahayakan manusia. ${ }^{18}$

Bahasan tentang dioksin dalam pembalut bermula dari penilaian EPA (Environmental Protection Agency) tahun 1996 yang menyatakan bahwa disetiap tampon (semacam pembalut) yang dibuat dengan komposisi yang melalui proses pemutihan akan menimbulkan senyawa organochlorine baru yaitu dioksin. Semua berawal dari bahan penyerap (absorbent agent) yang kebanyakan dibuat dari rayon, woodpulp (bubur kayu), kapas, kertas bekas/daur ulang, atau bahan-bahan sisa. Untuk membuat bahan tersebut kembali bersih dan berwarna putih, maka diperlukan sebuah proses yang cukup panjang. Awalnya, woodpulp dimasukkan dalam tong-tong besar yang kemudian dibersihkan supaya lebih putih. Sedangkan bagi pembalut yang ditambahkan rayon dan juga kapas untuk penyerapan yang lebih sempurna, maka bahan selulosa kayu 
dilarutkan dalam cairan asam. Pada proses ini saja, sudah beberapa kali bahan kimia ditambahkan. Kemudian proses berikutnya - terutama pada bahan yang berasal dari daur ulang (kertas) mengalami satu proses pencucian dengan detergen dan juga pemutih (bleaching) dengan chlorinisasi (pemberian klorin) yang memberi tampilan putih yang sempurna. Pada tahapan lain juga dilakukan proses penambahan formaldehide/formalin sebagai bahan anti basah (anti wet-agent). Ternyata setelah ditelusuri, zat-zat berbahaya tersebut didalam setiap pembalut mengandung sekitar 400 ppt (part per trillion). Jika dalam hidupnya seorang perempuan menggunakan sekitar 16.800 buah pembalut, maka tentu saja terdapat banyak zat-zat kimia berbahaya yang tinggal dalam tubuhnya. Jenis lain dari Dioksin yaitu polychlorinated dibenzofuran (PCDFs). Sumber-sumber dioksin antara lain berasal dari asap daerah industri/proses industri, makanan sehari-hari yang mengandung lemak (produk turun susu), berbisida, insektisida, asap rokok, bahan-bahan yang mengandung resin/rayon atau pemutih seperti tampon/pembalut, bahanbahan pembungkus makanan, proses klorinasi dimana semakin tinggi proses, semakin tinggi pula dioksin yang dihasilkan. ${ }^{19}$

Riset tentang dioksin dan bahayanya telah banyak dilakukan. Hasil penelitian menyatakan bahwa dioksin meningkatkan kejadian endometriosis dan pembesarannya pada primata (toxicol appl pharmacol, 2000), dioksin dapat mempengaruhi kesehatan reproduksi, sistem endokrin, toksik pada sistem imunitas dan perkembangan serta bersifat karsinogenik (US EPA, 2000), paparan dioksin selama 4 tahun pada monyet menyebabkan peningkatan kejadian endometriosis sekitar 7-10 tahun kemudian (fundam appl toxicol, 1993), dioksin walaupun dalam jumlah sedikit, terakumulasi dalam jaringan lemak (endometriosis association, 2004) dimana intervensinya sampai pada tingkat sel, yang akhirnya mempengaruhi DNA, metabolisme hormon, faktor pertumbuhan, reproduksi, endokrin, dan fungsi imunitas (Jurnal Environmental Health Perspective, 1995). Tidak ada dosis aman/ambang batas dioksin yang dapat menyebabkan kanker (Cancer Weekly, 2003). Efek lain yang dilaporkan akibat dioksi adalah abnormalitas perkembangan enamel pada gigi anak-anak, kelainan tiroid, patologi pada sistem syaraf periferal dan pusat, kerusakan sistem imunitas, endometriosis, diabetes (Wikipedia). Bahkan IARC-WHO (International Agency for Research on Cancer) WHO, berdasarkan evaluasi dampak pada manusia dan hewan yang dilakukan sejak tahun 1997 akhirnya pada tahun 2007 membuat peringatan akan efek samping dioksin dan dioksin 
digolongkan sebagai zat karsinogenik bagi manusia (known human carcinogen).

Jelas sudah, bahwa dioksin sangat berbahaya bagi kesehatan tubuh, dan tampon/pembalut menjadi salah satu sumber bertumpuknya dioksin pada sel-sel tubuh (terutama di organ reproduksi). Selain itu bagi manusia, lebih spesifiknya dioksin dapat menyebabkan endometriosis (penebalan dinding rahim), kanker payudara, serviks/leher rahim, rahim, infeksi vagina (vaginitis), sulit mempunyai keturunan (karena keputihan/infeksi vagina, kemandulan), rendahnya, bukan rusaknya sistem imunitas (menjadi mudah lelah, cepat emosi/marah, mudah sakit), kista, PMS (pre menstruation syndrome) berpa emosi yang tidak stabil dan nyeri pada perut, tumor organ reproduksi, keputihan, dan haid tidak teratur (karena ketidakseimbangan hormon).

Dioksin bisa masuk ke tubuh perempuan ketika sedang haid. Jika perempuan sedang haid atau cairan hariannya sedang banyak, maka cairan tersebut akan menetes ke permukaan pembalut/pantyliner yang dipakai. Cairan tersebut bersifat asam dan terjadi penguapan. Dioksin yang salah satu unsurnya oksigen (O) dan sifatnya oksidatif akan menguap (apalagi jika pembalut atau pantyliner dalam kondisi basah dan kelembaban tinggi), kemudian terbawa dalam permukaan vagina, lalu masuk ke rongga rahim melalui leher rahim (serviks). Dioksin akan menempel dan terikat pada jaringan lemak di dinding rahim. Dalam sel dioksin akan berikatan dengan aryl hydrocarbon receptor (AhR) yang diproduksi oleh berbagai organ termasuk hati, paru-paru, sel limfosit dan plasenta 1. Karena berikatan dengan AhR maka dioksin bergerak bebas dalam sel dan ketika berikatan dengan DNA dia dapat mengaktifkan atau mematikan DNA serta mengubah struktur DNA 1,2. Melalui mekanisme ini dioksin akan merusak/mengganggu sistem reproduksi, endokrin, fungsi imun, metabolisme hormon, faktor pertumbuhan dan memicu sel kanker 2,3.19

Metabolisme dan daya tahan tubuh perempuan berbeda-beda, sehingga efek zat dioxin pun ada yang langsung merasakan, ada pula yang setelah beberapa lama baru menimbulkan dampak penyakit yang sangat berbahaya. Banyak perempuan terjangkit infeksi vagina disebabkan oleh pemakaian pembalut yang tidak berkualitas. Jika seorang perempuan terjangkit infeksi vagina sejak usia 20 tahun, maka sedikitnya 6 tahun hidupnya akan dihabiskan untuk pengobatan \& perawatan infeksinya. ${ }^{20}$ Dr. Philip Tierno, Jr., Direktur Mikrobiologi Klinis di New York University Medical Center menyatakan bahwa “dioksin, meskipun ada di dalam lingkungan, mempunyai efek yang memperburuk ketika 
mereka menyentuh permukaan berlendir seperti vagina." De Vito lebih jauh mengakui bahwa dioksin mempunyai "waktu paruh yang sangat lama" - mampu bertahan dalam tubuh selama 11 tahun. "Jadi jika Anda terpapar 1 pikogram dioksn hari ini, maka setelah 11 tahun, masih tersisa setengah pikogram dalam tubuh anda," katanya. ${ }^{21}$

Adakalanya masyarakat tidak mengetahui dengan pasti bahaya dari produk yang digunakannya sehingga terus menerus menggunakannya tanpa rasa khawatir. Sebuah penelitian yang dilakukan oleh Irwin \& Millstein (1982) menemukan penurunan penggunaan tampon yang sangat signifikan setelah dipublikasikannya informasi mengenai penyakit yang disebabkan oleh bakteri yang ada di tampon. Sebanyak $81 \%$ subjek merubah perilaku mereka dalam menggunakan tampon. Pemakaian tampon sehari penuh bisa berbahaya dan membuat kita berisiko terkena Toxic Shock Syndrome (TSS), yaitu infeksi dari bakteri yang tumbuh di dalam tampon dan masuk ke dalam tubuh melalui vagina, kemudian masuk ke aliran darah dan menimbulkan gejala-gejala mual, muntah, pusing, gatal, merasa lemah, bahkan kalau tidak segera ditangani bisa menimbulkan kematian. ${ }^{22}$

Salah satu cara menghindari risiko pembalut yang kurang berkualitas adalah melakukan pengecekan terhadap pembalut yang kita gunakan. Ambil bagian inti di dalam pembalut untuk kemudian dicelupkan ke dalam segelas air putih dan aduk dengan sumpit. Usahakan gunakan gelas transparan sehingga lebih jelas. Jika terjadi perubahan warna air menjadi keruh dan produknya hancur seperti pulp dapat mengindikasikan produk pembalut tersebut kurang berkualitas dan banyak mengandung pemutih. Dari produk yang kurang berkualitas tersebutlah yang sering menyebabkan bagian intim organ keperempuanan selalu mengalami banyak masalah, seperti keputihan, gatal-gatal, iritasi, dll. Juga pemicu terjadinya kanker serviks/rahim. ${ }^{23}$

\section{Kanker Serviks}

Kanker serviks adalah keganasan yang terjadi pada leher rahim. Kanker serviks disebut juga kanker leher rahim atau kanker mulut rahim dimulai pada lapisan serviks. Kanker serviks merupakan jenis kanker yang paling banyak nomor tiga di dunia. Bahkan di Indonesia saja, setiap satu jam seorang perempuan meninggal karena kanker ini. Kanker servik disebut juga "silent killer" karena perkembangan kanker ini sangat sulit dideteksi. Perjalanan dari infeksi virus menjadi kanker membutuhkan waktu cukup lama, sekitar 10-20 tahun. Proses ini seringkali tidak disadari 
hingga kemudian sampai pada tahap pra-kanker tanpa gejala. Oleh karena itu pengertian kanker serviks mutlak dipahami oleh kaum perempuan di Indonesia. ${ }^{24}$ Kanker serviks, yang paling sering menimpa perempuan di usia 30-an dan 40-an, adalah bentuk kanker yang relatif jarang yang biasanya tumbuh sangat lambat. The American Cancer Society memperkirakan bahwa setiap tahun sekitar 13.000 kasus baru didiagnosis dan 4.100 perempuan meninggal akibat penyakit tersebut. ${ }^{25}$

Jumlah prevalensi perempuan pengidap kanker serviks di Indonesia terbilang cukup besar. Setiap hari, ditemukan 40-45 kasus baru dengan jumlah kematian mencapai 20-25 orang. Sementara jumlah perempuan yang berisiko mengidapnya mencapai 48 juta orang. Dokter Laila Nuranna SpOG(K), Kepala Divisi Onkologi Ginekologi Obstetri Fakultas Kedokteran Universitas Indonesia, mengatakan bahwa sebagian besar kasus kanker serviks yang terdeteksi di rumah sakit sudah stadium lanjut sehingga sulit diobati. "Jika kanker ditemukan lebih dini, penanganannya akan lebih mudah dan tingkat harapan hidup lebih besar," katanya saat Diskusi Kampanye dan Upaya Penanganan Kanker Serviks di Hotel Lumire Jakarta, Senin 12 April 2010.

Kanker serviks terbentuk sangat perlahan. Pertama, beberapa sel berubah dari normal menjadi sel-sel pra-kanker dan kemudian menjadi sel kanker. Ini dapat terjadi bertahun-tahun, tapi kadang-kadang terjadi lebih cepat. Perubahan ini sering disebut displasia. Mereka dapat ditemukan dengan tes Pap Smear dan dapat diobati untuk mencegah terjadinya kanker. Ada 2 jenis utama kanker serviks. Sekitar 8-9 dari 10 jenis yang ada adalah karsinoma sel skuamosa. Di bawah mikroskop, kanker jenis ini terbentuk dari sel-sel seperti sel-sel skuamosa yang menutupi permukaan serviks. Sebagian besar sisanya adalah adenokarsinoma. Kanker ini dimulai pada sel-sel kelenjar yang membuat lendir. Jarang terjadi, kanker serviks memiliki kedua jenis fitur diatas dan disebut karsinoma campuran. Jenis lainnya (seperti melanoma, sarkoma, dan limfoma) yang paling sering terjadi di bagian lain dari tubuh. ${ }^{26}$

\section{Penyebab Kanker Serviks}

Penyebab utama kanker serviks adalah infeksi Human Papilloma Virus (HPV atau virus papiloma manusia). Virus ini memiliki lebih dari 100 tipe, di mana sebagian besar di antaranya tidak berbahaya dan akan lenyap dengan sendirinya. Jenis virus HPV yang menyebabkan kanker serviks dan paling fatal akibatnya adalah virus HPV tipe 16 dan 18. Sekitar 70\% kejadian kanker serviks merupakan akibat dari HPV 16 dan HPV 18. Awalnya sel kanker berkembang dari serviks/mulut rahim yang 
letaknya berada di bawah rahim dan di atas vagina. Oleh sebab itu kanker serviks disebut juga kanker leher rahim atau kanker mulut rahim. Di mulut rahim ada dua jenis sel, yaitu sel kolumnar dan sel skuamosa. Sel skuamus ini sangat berperan dalam perkembangan kanker serviks. Kanker serviks dapat terjadi jika infeksi HPV tidak sembuh dalam waktu yang lama. Apalagi dengan sistem imun atau kekebalan tubuh yang rendah, infeksi akan mengganas dan menyebabkan sel kanker. Virus ini dapat menyebar melalui sentuhan: misalnya, ada virus HPV di tangan seseorang, lalu orang tersebut menyentuh daerah genital, maka daerah serviksnya dapat terinfeksi. Atau bisa juga dari kloset di WC umum yang sudah terkontaminasi virus. Oleh karena itu, sebelum duduk, closet harus selalu membersihkan dengan alcohol. ${ }^{27}$

Selain disebabkan oleh virus HPV, sel-sel abnormal pada leher rahim juga bisa tumbuh akibat paparan radiasi atau pencemaran bahan kimia yang terjadi dalam jangka waktu cukup lama. ${ }^{28}$ Selain itu, ada sejumlah faktor risiko atau penyebab kanker serviks: 1) Perempuan berusia di atas 40 tahun lebih rentan terkena kanker serviks. Semakin tua maka semakin tinggi risiko; 2) Faktor genetik tidak terlalu berperan dalam terjadinya kanker serviks, namun harus tetap berhati-hati dan melakukan tindakan pencegahan; 3) Hubungan seksual di usia yang terlalu muda, berganti-ganti partner seks, atau berhubungan seks dengan pria yang sering berganti pasangan. Virus HPV dapat menular melalui hubungan seksual. Seandainya seorang pria berhubungan seks dengan seorang perempuan yang menderita kanker servik, kemudian pria tersebut berhubungan sex dengan dengan yang lain, maka virus HPV dapat menular lagi; 4) Memiliki terlalu banyak anak (lebih dari 5 anak). Pada saat melahirkan secara alami, janin akan melewati serviks dan menimbulkan trauma pada serviks, yang dapat memicu aktifnya sel kanker. Semakin sering janin melewati serviks, semakin sering trauma terjadi, semakin tinggi resiko kanker serviks; 5) Keputihan yang berlangsung terus-menerus dan tidak diobati. Ada dua macam keputihan, yaitu normal dan tidak normal. Pada keputihan yang normal, lendir berwarna bening, tidak bau dan tidak gatal. Jika salah satu dari ketiga syarat tersebut tidak terpenuhi, artinya keputihan tidak normal. Segera konsultasi dengan dokter; 6) Membasuh atau membersihkan genital dengan air yang tidak bersih, misalnya air sungai atau air di toilet umum yang tidak terawat. Air yang kotor banyak mengandung kuman dan bakteri; 7) Pemakaian pembalut perempuan yang mengandung bahan dioksin; 8) Daya tahan tubuh yang lemah, kurangnya konsumsi vitamin 
C, vitamin E dan asam folat. Kebiasaan merokok juga menambah risiko kanker serviks. ${ }^{29}$

Menurut Minkin dan Wright (2003) Hispanik, penduduk asli Amerika, di Afrika perempuan memiliki kemungkinan yang lebih tinggi terkena kanker serviks dibandingkan perempuan kulit putih, mungkin karena kelompok-kelompok ini kurang memiliki akses ke perawatan kesehatan. Diet rendah dalam buah-buahan dan sayuran telah dikaitkan dengan peningkatan risiko kanker serviks dan kanker lainnya. Merokok meningkatkan risiko, karena memaparkan tubuh untuk bahan kimia karsinogenik yang diserap oleh paru-paru dan dibawa dalam aliran darah seluruh badan. Beberapa peneliti percaya bahwa diet kekurangan vitamin A dan $C$ mungkin memberikan kontribusi pada perkembangan kanker serviks, meskipun ini belum terbukti. ${ }^{30}$

Secara umum tanda dan gejala kanker serviks adalah terjadinya perdarahan vagina setelah aktivitas sexual atau diantara masa menstruasi. Sementara itu tanda lain yang mungkin timbul seperti hilangnya nafsu makan, nyeri tulang panggul dan tulang belakang, nyeri pada anggota gerak terutama kaki, terjadi pembengkakan pada area kaki, keluarnya faces menyertai urin melalui vagina, bahkan hingga terjadi patah tulang panggul. Kanker yang satu ini sesungguhnya bisa dicegah. Adapun cara paling populer untuk mendeteksi kanker ini secara dini adalah dengan pap smear. Cara ini sangat sederhana dan cepat diketahui adanya kelainan-kelainan sel leher rahim sehingga dapat mendeteksi displasia kanker tingkat dini, tanpa disertai gejala klinis. Pap smear adalah suatu metode pemeriksaan sel-sel yang diambil dari leher rahim dan kemudian diperiksa di bawah mikroskop untuk melihat perubahan-perubahan yang terjadi dari sel tersebut. Perubahan sel-sel leher rahim yang terdeteksi secara dini akan memungkinkan beberapa tindakan pengobatan diambil sebelum sel-sel tersebut dapat berkembang menjadi sel kanker. Makin dini kanker ini diketahui keberadaannya, makin mudah pula mengobatinya. ${ }^{31}$ Sedangkan menurut Hariyono Winarto dalam seminarnya pada tanggal 05-10-2008 tentang Pap Smear Sebagai Upaya Menghindari Kanker Leher Rahim Bagi Perempuan Usia Reproduksi, pengertian Pap Test (Pap Smear) adalah suatu pemeriksaan dengan cara mengusap leher rahim (scrapping) untuk mendapatkan sel-sel leher rahim kemudian diperiksa sel-selnya, agar dapat ditahui terjadinya perubahan atau tidak. Dari pengertian di atas, dapat disimpulkan bahwa Pap Smear adalah pemeriksaan usapan pada leher rahim untuk mengetahui adanya perubahan sel-sel yang abnormal yang diperiksa dibawah mikroskop. ${ }^{32}$ 
Jenis-jenis intervensi untuk mengontrol kanker adalah: pencegahan petama melalui (1) Immunisasi atau pengobatan terhadap infeksi yang dapat menyebabkan kanker. Terdapat dua jenis vaksin yang sangat penting yaitu vaksin untuk virus HPV untuk mencegah kanker serviks dan Vaksin Hepatitis B untuk mencegah kanker hati, (2) Program pengawasan terhadap alkohol dan tembakau secara nasional. Tembakau adalah penyebab utama kanker lung dan juga memiliki kontribusi untuk beberapa jenis kanker lain. Konsumsi alkohol yang berlebihan menyebabkan risiko kanker hati sekitar 20 sampai 30 persen. Program pengawasan alkohol dan tembakau yang efektif dapat berupa meningkatkan pajak untuk produk tersebut, membatasi atau melarang periklanannya, melarang merokok di tempat umum, mendidik masyarakat tentang risiko kesehatan dari konsumsi yang berlebihan, melakukan terapi untuk melawan ketergantungan, (3) Program mempromosikan diet yang memiliki banyak sayur dan buah dan lebih sedikit lemak. Pencegahan kedua dilakukan dengan mendeteksi kanker lebih dini dan pengobatan kanker. ${ }^{33}$

\section{Sumber Informasi Kesehatan Reproduksi}

Dalam beberapa budaya, orang tua dan anggota keluarga seperti tante, paman, kakak, kakek dan nenek, adalah sumber informasi yang mempengaruhi pengetahuan, kepercayaan, sikap, dan nilai bagi anakanak dan remaja. Mereka adalah panutan yang membentuk persepsi masyarakat akan peran gender dan mempengaruhi pilihan remaja mengenai perilaku seksualnya. Orang tua dan anggota keluarga lainnya sering memiliki kekuasaan untuk mengarahkan pertumbuhan anakanaknya kearah seksualitas yang sehat sebagai suatu hal yang alami, normal, dan mengalami perkembangan dalam siklus hidup mereka. Mereka dapat membantu anak mereka mengembangkan dan mempraktekkan pembuatan keputusan pribadi dan perilaku seksual yang bertanggungjawab. Terdapat beberapa bukti remaja yang hidup dalam lingkungan keluarga yang stabil dan dekat dengan orang tua lebih mungkin untuk tetap tidak melakukan hubungan seksual, menunda hubungan seksual, memiliki mitra lebih sedikit, dan menggunakan alat kontrasepsi. ${ }^{34}$

Di hampir semua masyarakat, mendidik anak tentang seks bukanlah tugas yang mudah bagi orang tua dan anggota keluarga lainnya. Banyak yang merasa tidak nyaman berbicara dengan anak tentang seks. Mungkin mereka enggan untuk mengekspos kekurangan mereka sendiri dalam pengetahuan tentang anatomi, fisiologi, atau informasi terkait 
lainnya, atau mungkin khawatir tentang berapa banyak informasi diberikan pada usia tertentu, didasarkan pada keyakinan tidak berdasar bahwa penyediaan informasi ini akan mengarahkan anak-anak muda untuk bereksperimen dengan seks. Banyak orang dewasa tidak menerima pendidikan seksualitas untuk diri mereka sendiri, dan beberapa memiliki ketakutan yang timbul dari pengalaman seksual mereka sendiri yang negatif. Anggota keluarga dewasa, oleh karena itu, cenderung menghindar dari mendidik secara aktif kaum muda tentang masalah yang berhubungan dengan seksualitas. Yang banyak gagal untuk disadari adalah bahwa tidak memberikan informasi atau menghindari pertanyaan orang muda dapat mengirim pesan negatif tentang seksualitas. Ketika orang muda tidak mendapatkan informasi di rumah, mereka mencari jawaban di tempat lain-dari teman sebaya, media atau pengamatan mereka dari orang dewasa lainnya. Hal ini dapat mengakibatkan informasi yang salah dan bertahan pada mitos yang salah, membuat orang muda rentan terhadap pengalaman seksual yang tidak diinginkan dan tidak terlindungi. Hasilnya mungkin berupa kehamilan yang tidak direncanakan, infeksi menular seksual, dan harga diri yang rendah. Dalam budaya di mana anak-anak muda muda mengatakan mereka ingin mendapatkan informasi dari anggota keluarga dewasa tentang seks dan reproduksi, mendidik orang tua dan anggota keluarga lainnya dapat membantu orang dewasa merasa lebih percaya diri dalam menghadapi pertanyaan-pertanyaan kesehatan reproduksi dan keprihatinan kaum muda. ${ }^{35}$

Terdapat banyak literatur yang berkembang mengenai peran orang tua dalam maslah seksualitas remaja dan kesehatan reproduksi di seluruh dunia, termasuk Sub-Sahara Africa. Selain itu, organisasi internasional dan non-pemerintah telah mulai melaksanakan kegiatan yang secara eksplisit membahas peran orang tua dalam meningkatkan kesehatan seksual dan reproduksi remaja. Lebih dari 30 program tersebut baru-baru ini dijelaskan dalam sebuah review oleh Organisasi Kesehatan Dunia atau WHO. Beberapa program, seperti kampanye Straight Talk Uganda, telah menunjukkan kemauan umum dari orang tua dan orang dewasa lain untuk menciptakan lingkungan yang mendukung bagi kaum muda. Program-program ini dapat berupa penyediaan informasi dan jasa kesehatan seksual dan reproduksi, utamanya ketika orang tua sendiri merasa tidak nyaman berbicara langsung dengan remaja tentang topik tersebut. program lain, seperti Families Matter! di Kenya, bekerja secara langsung dengan orang tua dan anak-anak mereka untuk meningkatkan komunikasi intrafamily tentang seksualitas dan risiko seksual. ${ }^{36}$ 
Seperti telah dikemukakan, jika informasi tentang seksualitas dan kesehatan reproduksi tidak diperoleh dari lingkungan terdekatnya, para perempuan biasanya menggunakan berbagai sumber informal untuk mendapatkan informasi dari lingkungan eksternalnya, yaitu media cetak seperti buku, majalah perempuan, brosur tentang kesehatan, koran dan bacaan-bacaan keagamaan. Informasi yang dikumpulkan dari sumbersumber ini seringnya hanya sebagian saja atau tidak benar, dikarenakan kenyataan bahwa banyak materi-materi ini memang bukan ditujukan untuk sarana pendidikan. Beberapa majalah populer perempuan Indonesia seperti Gadis, Kartini dan Femina menyediakan kolom artikel rutin berkatian dengan reproduksi dan seksualitas yang cenderung akurat, berdasarkan penelitian yang baik, dan ditampilkan dengan gaya yang sangat bisa diterima. Bentuk media masa lain yang juga memegang peran yang semakin meningkat dalam memberikan informasi mengenai reproduksi dan seksualitas adalah musik, internet, televisi satelit, radio, dan film. Namun, sekali lagi, informasi dan nilai-nilai yang diinterpretasikan oleh generasi muda dari sumber-sumber ini jarang dibuat dengan tujuan untuk pendidikan. Di sekolah formal, pendidikan tentang reproduksi dan seksualitas biasanya terbatas pada pelajaran biologi. Menurut Utomo (2001), terdapat kegagalan sekolah untuk menyediakan pendidikan seks dan reproduksi secara komprehensif (Bennett, 2005). ${ }^{37}$ hal merupakan salah satu pendorong para perempuan mencari informasi dari sumber lainnya.

Menurut penelitian Tirtawati (2005), sumber-sumber informasi mempunyai pengaruh terhadap pengetahuan kesehatan reproduksi remaja. Sumber-sumber informasi diperoleh dari TV (98\%), guru $(96 \%)$, teman $(91 \%)$, orang tua $(40 \%)$, petugas kesehatan $(24 \%)$, petugas KB $(16 \%)$, dan dari radio $(66 \%){ }^{38}$ Eulali menambahkan, percakapan kesehatan reproduksi antara orang tua dan anak-anak mempengaruhi perilaku seksual remaja, tapi hanya jika orang tua berkomunikasi dengan terampil, jelas, nyaman, dan secara terbuka tentang seksualitas dan konsekuensi kesehatan dari perilaku seksual. ${ }^{39}$

\section{HASIL PENELITIAN DAN PEMBAHASAN}

Responden dalam penelitian memiliki usia yang berkisar antara 23 tahun sampai dengan 53 tahun. Mayoritas responden menyelesaikan S2 $(53 \%)$, S1 $(28 \%)$, S3 (11\%), dan SMA (8\%). Pekerjaan responden $61 \%$ adalah dosen, sisanya guru dan pegawai masing-masing 19\%. Gaji responden dibawah 1 juta dan antara 7 sd 9 juta ada 3\%, antara 1-3 dan 3-5 masing-masing $39 \%$ dan $5-7$ juta $17 \%$. Sampel dalam penelitian ini 
sebagian besar memiliki gaji antara satu sampai dengan tujuh juta rupiah perbulannya.

Gambar 1 menunjukkan sumber informasi yang digunakan responden untuk mengetahui segala sesuatu tentang kesehatan reproduksi.

Gambar 1

Sumber Informasi Kesehatan Reproduksi

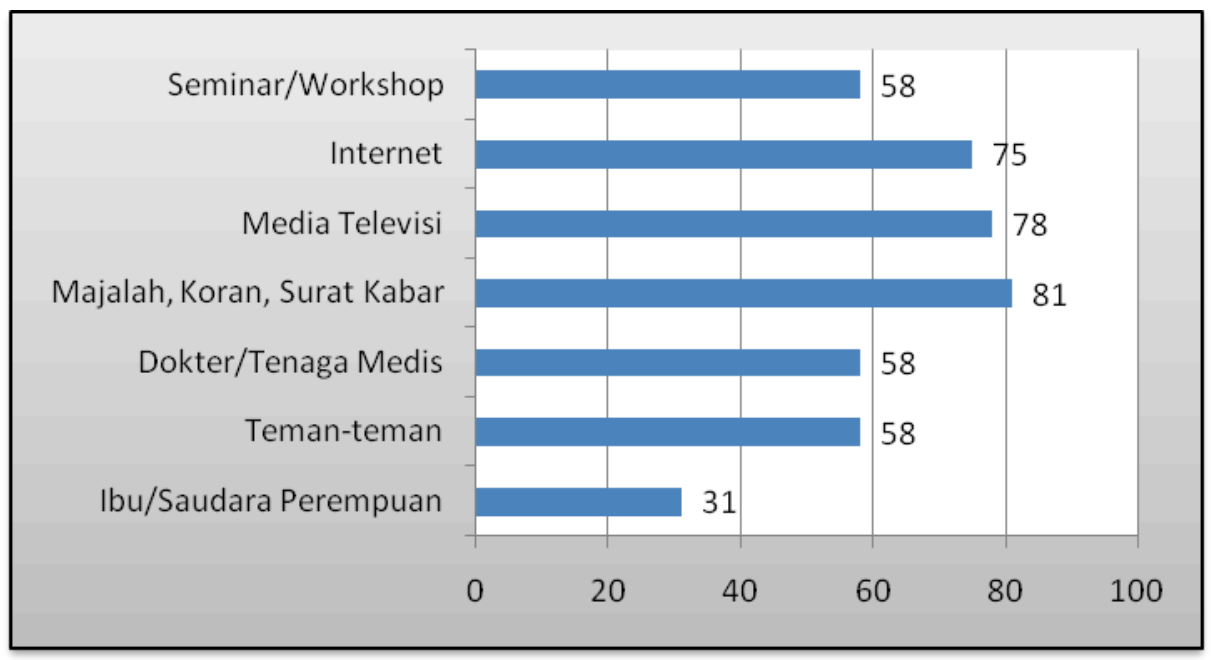

Berdasarkan data pada Gambar 1 diketahui bahwa sumber informasi terbanyak yang digunakan responden adalah media cetak berupa majalah, koran, atau suratkabar. Selain itu sumber informasi yang digunakan responden adalah televisi, internet, seminar, dokter, dan teman-teman. Keluarga, khususnya ibu atau saudara perempuan, justru menjadi sumber informasi yang paling jarang digunakan. Hal ini barangkali disebabkan oleh masih malunya keluarga membicarakan mengenai masalah reproduksi sehingga para perempuan mencari informasi justru dari lingkungan eksternalnya.

Berkaitan dengan jumlah sumber informasi yang digunakan, $14 \%$ responden hanya menggunakan satu sumber informasi, 3\% nya menggunakan dua sumber informasi, $11 \%$ responden menggunakan tiga sumber informasi, 22\% responden menggunakan empat sumber informasi, 19\% menggunakan lima sumber informasi, 14\% responden menggunakan enam sumber informasi, dan terakhir 17\% responden menggunakan tujuh sumber informasi. 
Tabel 1 berikut menampilkan resume perilaku konsumen perempuan berkaitan dengan informasi mengenai kesehatan reproduksinya.

Tabel 1

Kesehatan Reproduksi Perempuan

\begin{tabular}{|c|c|c|c|c|c|c|}
\hline \multirow[t]{2}{*}{ No } & \multirow[t]{2}{*}{ Butir Pernyataan } & \multicolumn{5}{|c|}{ Tanggapan } \\
\hline & & SS & $\mathrm{S}$ & $\mathrm{N}$ & TS & STS \\
\hline KR1 & $\begin{array}{l}\text { Saya meluangkan waktu khusus untuk } \\
\text { menambah pengetahuan mengenai } \\
\text { kesehatan reproduksi perempuan. }\end{array}$ & 19 & 47 & 25 & 8 & - \\
\hline KR2 & $\begin{array}{l}\text { Jika dalam suatu majalah terdapat artikel } \\
\text { yang membahas kesehatan reproduksi } \\
\text { perempuan, saya memprioritaskan } \\
\text { membacanya terlebih dahulu. }\end{array}$ & 42 & 44 & 11 & 3 & - \\
\hline KR3 & $\begin{array}{l}\text { Informasi tentang kesehatan reproduksi } \\
\text { perempuan, tidak terlalu menarik perhatian } \\
\text { saya. }\end{array}$ & & 6 & 14 & 36 & 44 \\
\hline KR4 & $\begin{array}{l}\text { Biasanya saya mendapatkan pengetahuan } \\
\text { tentang reproduksi perempuan secara tidak } \\
\text { sengaja. }\end{array}$ & & 36 & 19 & 39 & 6 \\
\hline
\end{tabular}

Tabel diatas menyatakan bahwa lebih dari $60 \%$ responden meluangkan waktu khusus untuk menambah pengetahuan mengenai kesehatan reproduksi perempuan, memprioritaskan membaca artikel tentang kesehatan reproduksi perempuan. $80 \%$ dari responden merasa informasi tentang kesehatan reproduksi selalu menarik perhatian mereka. Hanya $45 \%$ yang memang mencari informasi mengenai kesehatan reproduksi dengan sengaja.

Salah satu cara mendeteksi adanya kanker serviks adalah dengan melakukan Pap Smear. Dalam penelitian ini, lebih banyak responden belum melakukan Pap Smear yaitu 44\% responden, sudah pernah melakukan papsmear dan $54 \%$ belum pernah melakukan papsmear. Sebanyak 50\% responden berniat melakukannya, sementara $11 \%$ responden tidak berniat melakukannya. Alasan responden adalah malu $(11 \%)$, biayanya terlalu mahal $(6 \%)$, tidak terlalu berpengaruh terhadap kesehatan (3\%), tidak berani untuk melakukannya (19\%), dan lebih baik tidak tahu daripada menimbulkan ketakutan $(14 \%)$. Selain itu beberapa 
alasan lain adalah belum sempat, belum ada waktu, belum termotivasi, dan merasa masih sehat.

Secara grafis, alasan responden belum melakukan Pap Smear dapat dilihat pada Gambar 2.

Gambar 2

Alasan Tidak Mau Melakukan Pap Smear

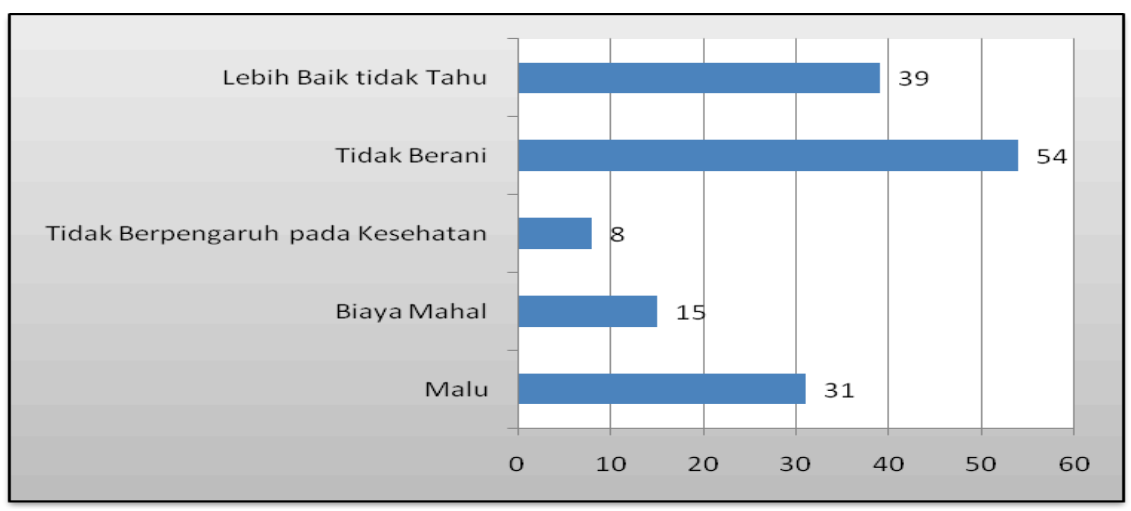

Perilaku perempuan dalam penelitian ini antara lain selalu menggunakan pembalut favorit dengan merek yang sama (lebih dari $60 \%$ ). Walaupun begitu, jika produk yang biasa dipakai tidak tersedia, mereka akan dengan sangat mudah berpindah ke merek lain. Dari sisi pemasaran, hal ini berarti konsumen memiliki loyalitas yang rendah dan juga tidak terlalu memperdulikan merek pembalut asal nyaman dipakai. Sepertiga responden tidak pasti apakah terdapat perbedaan tingkat higienitas antar pembalut yang beredar di pasaran, namun persentase terbesar $(47 \%)$ percaya bahwa terdapat perbedaan tingkat higienitas. Sebanyak $36 \%$ responden percaya bahwa pembalut yang beredar memiliki komposisi bahan yang aman bagi kesehatan, namun separuhnya menjawab netral untuk pernyataan mengenai amannya pembalut yang banyak beredar bagi kesehatan.

Secara pribadi seorang dokter ginekolog menyatakan bahwa jika memang pembalut yang beredar saat ini mengandung dioksin yang berbahaya bagi kesehatan, pemerintah melalui lembaga yang berwenang seperti BPPOM seharusnya sudah mengambil tindakan. Beliau sendiri sehari-harinya menggunakan kombinasi antara pembalut tradisional dan pembalut yang berharga lebih mahal dibandingkan yang banyak beredar di pasaran. $47 \%$ responden dalam penelitian ini setuju dan sangat setuju bahwa harga pembalut merupakan faktor yang sangat mempengaruhi keputusan memilih pembalut. Sebagian besar responden dalam penelitian 
ini tidak setuju bahwa penggunaan pembalut merupakan salah satu penyebab kanker rahim, sisanya 33\% dan $28 \%$ menyatakan netral dan setuju bahwa penggunaan pembalut merupakan salah satu penyebab kanker rahim. Sejalan dengan pendapat sebelumnya bahwa harga merupakan faktor yang sangat mempengaruhi keputusan memilih pembalut, maka lebih dari separuh responden tidak setuju dan sangat tidak setuju bahwa penggunaan pembalut yang lebih mahal berarti mengurangi risiko kanker. Namun lebih dari separuh responden akan mempertimbangkan menggunakan cara tradisional dengan kain yang dicuci ulang jika memang terbukti pembalut yang beredar sekarang dapat menyebabkan kanker rahim. Lebih lengkapnya, jawaban responden dapat dilihat pada Tabel 2 .

Tabel 2

Perilaku Penggunaan Pembalut

\begin{tabular}{|c|c|c|c|c|c|c|}
\hline \multirow[t]{2}{*}{ No } & \multirow[t]{2}{*}{ Butir Pernyataan } & \multicolumn{5}{|c|}{ Tanggapan } \\
\hline & & SS & $S$ & $\mathrm{~N}$ & TS & STS \\
\hline PP1 & $\begin{array}{l}\text { Saya selalu menggunakan pembalut } \\
\text { dengan merek yang sama. }\end{array}$ & 8 & 56 & 22 & 14 & \\
\hline PP2 & $\begin{array}{l}\text { Saya memiliki merek favorit dalam } \\
\text { menggunakan pembalut. }\end{array}$ & 8 & 56 & 25 & 8 & 3 \\
\hline PP3 & $\begin{array}{l}\text { Jika pembalut yang biasa saya pakai tidak } \\
\text { tersedia di toko, maka saya akan membeli } \\
\text { merek lain. }\end{array}$ & 8 & 61 & 14 & 17 & \\
\hline PP4 & $\begin{array}{l}\text { Asalkan nyaman dipakai, saya tidak } \\
\text { perduli merek apapun pembalutnya. }\end{array}$ & 17 & 39 & 14 & 31 & \\
\hline PP5 & $\begin{array}{l}\text { Menurut saya, tidak terdapat perbedaan } \\
\text { tingkat higienitas pembalut antar berbagai } \\
\text { merek pembalut yang beredar di pasaran. }\end{array}$ & 3 & 19 & 31 & 33 & 14 \\
\hline PP6 & $\begin{array}{l}\text { Saya percaya komposisi bahan yang } \\
\text { digunakan sebagai pembalut aman bagi } \\
\text { kesehatan. }\end{array}$ & 3 & 33 & 50 & 14 & \\
\hline PP7 & $\begin{array}{l}\text { Harga pembalut merupakan faktor yang } \\
\text { sangat mempengaruhi pilihan saya }\end{array}$ & 11 & 36 & 42 & 11 & \\
\hline PP8 & $\begin{array}{l}\text { Saya percaya bahwa penggunaan pembalut } \\
\text { merupakan salah satu penyebab kanker } \\
\text { rahim. }\end{array}$ & & 28 & 33 & 39 & \\
\hline PP9 & $\begin{array}{l}\text { Menggunakan pembalut dengan harga } \\
\text { lebih mahal berarti mengurangi risiko }\end{array}$ & & 14 & 33 & 47 & 6 \\
\hline
\end{tabular}




\begin{tabular}{|c|l|c|c|c|c|} 
PP1 & $\begin{array}{l}\text { terjadinya kanker rahim } \\
\text { Saya mempertimbangkan akan } \\
0\end{array}$ & $\begin{array}{l}\text { menggunakan kain yang dapat dicuci } \\
\text { ulang jika terbukti pembalut yang beredar } \\
\text { sekarang dapat menyebabkan kanker } \\
\text { rahim. }\end{array}$ & 31 & 25 & 22 \\
\hline
\end{tabular}

\section{SIMPULAN}

Hasil penelitian menunjukkan bahwa sumber informasi yang paling banyak digunakan perempuan dalam mencari informasi kesehatan reproduksi adalah media cetak berupa majalah, koran atau surat kabar. Secara umum, responden dalam penelitian ini sudah memiliki perhatian yang tinggi terhadap kesehatan reproduksinya. Meskipun sebagian mereka belum pernah melakukan Pap Smear, animo responden untuk melaksanakannya cukup tinggi walau terdapat beberapa hambatan.

Temuan penelitian lainnya adalah responden memiliki merek pembalut tertentu yang menjadi prioritas, namun disisi lain, responden juga tidak loyal jika produk merek tersebut tidak tersedia saat dibutuhkan. Mengingat produk pembalut merupakan produk dengan tingkat urgensi yang tinggi, ketersediaan menjadi salah satu faktor penting untuk kesuksesan penjualannya. Terkait dengan adanya pemberitaan zak kimia berupa dioksin yang mungkin terdapat pada produk pembalut, responden mempertimbangkan akan beralih ke produk pengganti jika terbukti produk yang banyak beredar di pasaran dapat menyebabkan timbulnya gangguan kesehatan reproduksi.

Terdapat banyak faktor yang dapat mempengaruhi kesehatan reproduksi perempuan. Mengingat kesehatan reproduksi sangat penting untuk menunjang produtivitas kerja perempuan dan juga kelanjutan generasi berikut, perempuan perlu memperhatikan segala sesuatu yang berkaitan dengan kesehatan reproduksinya. Berbagai cara dapat dilakukan untuk meningkatkan kesehatan reproduksi baik secara individu maupun kelembagaan. Hal yang barangkali paling mudah untuk dilakukan adalah secara individu, para perempuan selalu berperilaku yang dapat menjaga kesehatan reproduksinya.

Berdasarkan telaah pustaka, diketahui bahwa terdapat kemungkinan pembalut yang beredar di pasaran mengandung dioksin yang sangat berbahaya bagi kesehatan reproduksi perempuan. Oleh karena itu, sangat diharapkan pihak yang berwenang baik dari lembaga pemerintah maupun Yayasan Lembaga Konsumen Indonesia mengambil peran aktif untuk melindungi masyarakat atau konsumen khususnya 
perempuan agar terhindar dari paparan zat yang dapat menyebabkan masalah dalam kesehatan reproduksinya. Begitu pula diharapkan kepada para produsen sebagai bentuk tanggung jawab sosialnya agar tidak semata mengejar keuntungan, akan tetapi juga memperhatikan keamanan masyarakat yang menjadi pasar sasarannya.

\section{Endnotes:}

1 Kogi, K. 1997. Current problems - emerging issues in occupational and environmental health, Environmental Management and Health, Vol. 8 Iss: 5 pp. 167 - 169

2 http://repository.usu.ac.id/bitstream/123456789/23575/5/Chapter\%20I.pdf

3 Middleberg, M. I. 2004. Promoting Reproductive Security in Developing Countries, New York, Kluwer Academic Publisher, Hal 1.

4 http://belajarpsikologi.com/kesehatan-reproduksi-remaja/.

5 (2006) "Vietnam - UN begins five-year plan for reproductive healthcare", International Journal of Health Care Quality Assurance, Vol. 19 Iss: 6.

6 (2007) "World Health Organization - Statement by Dr Margaret Chan, WHO DirectorGeneral, on the occasion of International Women's Day", International Journal of Health Care Quality Assurance, Vol. 20 Iss: 4.

7 Ondimu, K., N. 2001. Determinants of Perinatal Health Problems in Kisumu District, Kenya, International Journal of Health Care Quality Assurance, Vol. 14 Iss: 5 pp. 200 - 211.

8 Sandip Anand, R.K. Sinha, (2010), Quality differentials and reproductive health service utilisation determinants in India, International Journal of Health Care Quality Assurance, Vol. 23 Iss: 8 pp. 718 - 729

9 Middleberg, hal, 14

10 Bhatt, R.V. 2000. Environmental Influence on Reproductive Health, International Journal of Gynecology \& Obstetrics, Volume 70, Issue 1, 69-75.

11 Derbyshire, E. 2007. Taking it a step too far? Physical activity and infertility, Nutrition $\mathcal{E}$ Food Science, Vol. 37 Iss: 5 hal 314-316

12 Caren Grown, Elissa Braunstein, Anju Malhotra, 2006. Trade Liberalization and Reproductive Health in Developing Economics, , London Zed Books Ltd, Hal 7-8

13 Middleberg, hal, 17-18

14 Adeniyi O. Olaleye, Olayinka A. Anoemuah, Oladapo A. Ladipo, Grace E. Delano, Grace F. Idowu, 2007. Sexual Behaviours and Reproductive Health Knowledge among In-School Young People with Disabilities in Ibadan, Nigeria", Health Education, Vol. 107 Iss: 2, pp.208 - 218

15 http://repository.usu.ac.id/bitstream/123456789/23575/5/Chapter\%20I.pdf.

16 http://sehatdarialam.wordpress.com

17 http://sehatpluscantik.blogspot.com/2011/06/mengapa-pembalut-penting-bagiperempuan.html

18 Heather Guidone, Dioxin and Feminine Hygiene Products http:/ / www.insiderreports.com/storypage.asp?storyID=20001533\&ChanID=HQ

19 http://sehatpluscantik.blogspot.com/2011/06/mengapa-pembalut-penting-bagiperempuan.html 
20 Amijaya, S. 2010. Apakah Sebenarnya Mahkota Perempuan? Kenapa Harus ke Pembalut Herbal?, http://sastraamijaya.wordpress.com/2010/06/21/apakahsebenarnya-mahkota-perempuan-kenapa-harus-ke-pembalut-herbal/

21 Guidone, H, Dioxin and Feminine Hygiene Products http://www.insiderreports.com/storypage.asp?storyID=20001533\&ChanID=HQ

22 Irwin, C., E., \& Millstein, S., G. 1982. Emerging Pattern of Tampon Use in the Adolescent Female: The Impact of Toxic Shock Syndrome, AJPH, Vol. 72, No. 5, 464467.

23 http://sehatdarialam.wordpress.com.

24 http:// kankerserviks.org/info/penyebab-kanker-serviks.html

25 Minkin, M.J., dan Wright, C., V. 2003. The Yale Guide to Women's Reproductive Health, New Haven and London, Yale University Press.

26 http://www.cancerhelps.com/kanker-serviks.htm

27 http://kankerserviks.org/info/penyebab-kanker-serviks.html

$28 \mathrm{http}: / /$ tentangkanker.com/search/data-penderita-kanker-serviks

29 http://kankerserviks.org/info/penyebab-kanker-serviks.html

30 Minkin, M.J., dan Wright, C., V. 2003.

$31 \mathrm{http}: / /$ sehatdarialam.wordpress.com/pembalut-alami/bahaya-pembalut-biasa/,.

32 http://ayurai.wordpress.com/2009/04/15/pap-smear/

33 2007. Controlling Cancer in Developing Countries: Prevention and Treatment Strategies Merit Further Study, www.dcp2.org

${ }^{34} \mathrm{http}: / /$ www.pathfind.org/pf/pubs/focus/IN\%20FOCUS/inv_parents.htm hal 1

35 http://www.pathfind.org/pf/pubs/focus/IN\%20FOCUS/inv_parents.htm hal 7

36 Biddlecom, A., 2009. Role of Parents in Adolescent Sexual Activity And Contraceptive Use in Four African Countries, International Perspective on Sexual and Reproducitve Health, Vol. 32 Number, 2. June, pp. 72-81.

37 Bennett, L., R. 2005. Women, Islam, and Modernity: Single Women, Sexuality and Reproductive Health in Contemporary Indonesia, New York, RoutledgeCurzon.

38 http://etd.eprints.ums.ac.id/10157/4/J410060025.pdf

39 Laschever, E. 2011. The Buzz About the Birds and the Bees, http://www.kon.org/ urc/v10/laschever.html

\section{DAFTAR PUSTAKA}

Adeniyi O. Olaleye, Olayinka A. Anoemuah, Oladapo A. Ladipo, Grace E. Delano, Grace F. Idowu. 2007. Sexual Behaviours and Reproductive Health Knowledge among In-School Young People with Disabilities in Ibadan, Nigeria", Health Education, Vol. 107 Iss: 2, pp.208 - 218

Amijaya, S. 2010. Apakah Sebenarnya Mahkota Perempuan? Kenapa Harus ke Pembalut Herbal?

http:// sastraamijaya.wordpress.com/2010/06/21/apakah-sebenarnyamahkota-perempuan-kenapa-harus-ke-pembalut-herbal/ 
Bennett, L., R. 2005. Women, Islam, and Modernity: Single Women, Sexuality and Reproductive Health in Contemporary Indonesia. New York: RoutledgeCurzon.

Bhatt, R.V. 2000. Environmental Influence on Reproductive Health, International Journal of Gynecology E Obstetrics, Volume 70, Issue 1, 69-75.

Biddlecom, A. 2009. Role of Parents in Adolescent Sexual Activity And Contraceptive Use in Four African Countries, International Perspective on Sexual and Reproducitve Health, Vol. 32 Number, 2. June, pp. 72-81

Caren Grown, Elissa Braunstein, Anju Malhotra. 2006. Trade Liberalization and Reproductive Health in Developing Economics. London: Zed Books Ltd.

Derbyshire, E. 2007. Taking it a step too far? Physical activity and infertility, Nutrition $\mathcal{E}$ Food Science, Vol. 37 Iss: 5 pp. 313 - 318.

Guidone, H, Dioxin and Feminine Hygiene Products http:/ / www.insiderreports.com/storypage.asp?storyID=20001533 \&ChanID $=\mathrm{HQ}$

http://sehatdarialam.wordpress.com/pembalut-alami/bahaya-pembalutbiasa/, (online, diakses tanggal 23 April 2012)

http://etd.eprints.ums.ac.id/10157/4/J410060025.pdf

http://repository.usu.ac.id/bitstream/123456789/23575/5/Chapter\%20I. pdf

http:// belajarpsikologi.com/kesehatan-reproduksi-remaja/.

http:// sehatpluscantik.blogspot.com/2011/06/mengapa-pembalutpenting-bagi-perempuan.html

http://kankerserviks.org/info/penyebab-kanker-serviks.html

http://www.cancerhelps.com/kanker-serviks.htm

http://tentangkanker.com/search/data-penderita-kanker-serviks

http://ayurai.wordpress.com/2009/04/15/pap-smear/

http://www.pathfind.org/pf/pubs/focus/IN\%20FOCUS/inv_parents.ht $\mathrm{m}$.

Irwin, C., E., \& Millstein, S., G. 1982. Emerging Pattern of Tampon Use in the Adolescent Female: The Impact of Toxic Shock Syndrome, AJPH, Vol. 72, No. 5, 464-467. 
Kogi, K. 1997. Current problems - emerging issues in occupational and environmental health, Environmental Management and Health, Vol. 8 Iss: 5 pp. $167-169$

Laschever, E. 2011. The Buzz About the Birds and the Bees, http://www.kon.org/urc/v10/laschever.html

Middleberg, M. I. 2004. Promoting Reproductive Security in Developing Countries. New York: Kluwer Academic Publisher.

Minkin, M.J., dan Wright, C., V. 2003. The Yale Guide to Women's Reproductive Health. New Haven and London: Yale University Press.

Ondimu, K., N. 2001. Determinants of Perinatal Health Problems in Kisumu District, Kenya, International Journal of Health Care Quality Assurance, Vol. 14 Iss: 5 pp. 200 - 211.

Sandip Anand, R.K. Sinha, (2010), Quality differentials and reproductive health service utilisation determinants in India, International Journal of Health Care Quality Assurance, Vol. 23 Iss: 8 pp. 718 - 729

(2006) "Vietnam - UN begins five-year plan for reproductive healthcare", International Journal of Health Care Quality Assurance, Vol. 19 Iss: 6.

(2007) "World Health Organization - Statement by Dr Margaret Chan, WHO Director-General, on the occasion of International Women's Day", International Journal of Health Care Quality Assurance, Vol. 20 Iss: 4.

(2007) Controlling Cancer in Developing Countries: Prevention and Treatment Strategies Merit Further Study, www.dcp2.org 